\title{
Energy Use and Environmental Impact of New Alternative Fuel Mix in Electricity Generation in Malaysia
}

\author{
Abul Quasem Al-Amin ${ }^{1, *}$, Chamhuri Siwar ${ }^{2}$ and Abdul Hamid Jaafar ${ }^{3}$ \\ ${ }^{I}$ Institute for Environment and Development (LESTARI), Universiti Kebangsaan Malaysia, Bangi 43600, Selangor Da- \\ rul Ehsan, Malaysia \\ ${ }^{2}$ Institute for Environment and Development (LESTARI), Universiti Kebangsaan Malaysia, Bangi 43600, Selangor Da- \\ rul Ehsan, Malaysia \\ ${ }^{3}$ Faculty of Business and Economics, Universiti Kebangsaan Malaysia, Bangi 43600, Selangor Darul Ehsan, Malaysia
}

\begin{abstract}
Production of electricity by burning coal, oil, and natural gas produces $\mathrm{CO}_{2}, \mathrm{SO}_{2}, \mathrm{NO}_{\mathrm{x}}$, etc. which act as greenhouse gases and pollutants. This paper examines fuel use, energy production, and the quantities of these gases produced in the Malaysian economy during the years 1991 and 2000. Input-output (Leontief) analysis is used in this study to enable calculation of energy demand and pollution effects throughout the economy. This study also estimates changes in emissions related to changes in fuel mix projected in Vision 2020. It is found that the fuel mix envisioned by the Fuel Diversification Strategy, designed to reduce Malaysia's dependence on fuel oil and increase its energy security would increase undesired emissions. This study may find use in formulation of energy policy in Malaysia.
\end{abstract}

Keywords: Input-output analysis, electricity, pollution, Malaysian economy.

\section{INTRODUCTION}

Electric power industry in Malaysia has played an important role in the dramatic economic development. Malaysia has been privileged to be relatively well endowed with both fossil and renewable sources of energy and have succeeded, so far, in meeting the country's demand for energy. It is evident that there has been some significant growth in the energy scene in Malaysia in the past years. Primary energy supply, which was recorded at $20,611 \mathrm{ktoe}^{1}$ (kilo tonne of oil equivalent) in 1991, increased to 50,658 ktoe in 2000 and increased further to 54,194 ktoe in 2003. Final energy demand, which was recorded at 14,560 ktoe in 1991, increased to 29,996 ktoe in 2000 and increased further in 2003 to 34,586 ktoe $[1,2]$. Electricity demand, which was 22,273 GWh (Giga Watts Hour) in 1991, increased to $60,299 \mathrm{GWh}$ in 2000 and also increased further 71,159 GWh in 2003 [1, 2].

Malaysia is a newly industrialized and fast developing country with over 4.5 GDP growth rates [3, p.46]. The growing demand for electricity is causing negative impact on the energy such as petroleum fuels and gas as well as on the environment. The use of electrical energy immensely increased in recent years and the demand of this will further increase in an accelerated fashion. Basically, oil, coal, gas and hydropower are the raw materials for electricity generation and

*Address correspondence to this author at the Institute for Environment and Development (LESTARI), Universiti Kebangsaan Malaysia, Bangi 43600, Selangor Darul Ehsan, Malaysia; Tel: +603-89214161; E-mail: amin_cant@yahoo.com

\footnotetext{
${ }^{1}$ Mtoe $($ million ton oil equivalent $)=$ ktoe $/ 1000$
}

burning fossil fuels such as coal or oil creates environmental emissions by-products such as $\mathrm{CO}_{2}, \mathrm{SO}_{2}$ and $\mathrm{NO}_{\mathrm{x}}$ (see: Table 1). Particularly fuels used to generate electricity in conventional power plants produce $\mathrm{CO}_{2}, \mathrm{SO}_{2}$ and $\mathrm{NO}_{\mathrm{x}}$. High concentration of these pollutants is also responsible for the global warming.

In Malaysia, electricity generation is mostly fossil-based, in particular natural gas and oil. To ensure the security of energy supply, the Four-fuel Diversification Strategy ${ }^{2}$ was introduced in 1981 as an extension of the 1979 National Energy Policy. Subsequently, the Five-fuel Diversification Strategy ${ }^{3}$ was introduced in 1999 and will continue until 2020. The rationale for this policy initiative was to reduce Malaysia's over dependency on oil in overall energy consumption. This policy in the electricity sector aimed for a gradual change in fuel use from $74.9 \%$ gas, $9.7 \%$ coal, $10.4 \%$ hydro, and $5 \%$ petroleum in the year 2000 to $40 \%$ gas, $30 \%$ hydro, $29 \%$ coal, and only $1 \%$ petroleum by the year 2020 [3].

\footnotetext{
${ }^{2}$ Fuel Diversification Strategy is the Malaysian energy policy which focuses economic energy consumption in the whole economy and provides guideline to reduce Malaysia's over reliance on specific fuel-type (i.e. gas, oil, coal) and to achieve a more balanced supply mix between natural gas, oil, and coal in the Malaysian energy sector. Based on the coal reserves and requirement rate, is has been estimated that coal could still contribute to the energy mix for the next 285 years [1,3]. A more sustainable energy mix for Malaysia (in the longer term), the internal estimation shown that greater contribution of coal would be about $40-45 \%$, while natural gas less than $50 \%$ [3]. Thus, the demand for coal for electricity generation is projected to increase drastically (6.03 million tones in 2000 to between 19 and 20 million tones per annum by 2010) [1-3].

${ }^{3}$ Fifth Fuel Diversification Strategy is the extension of Four Fuel Diversification Strategy where renewable energy included.
} 
Table 1. Approximate Heats of Combustion and $\mathrm{CO}_{2}$ Emissions for Common Fuels

\begin{tabular}{|c|c|c|c|c|c|}
\hline Fuel & $\mathrm{MJ} / \mathrm{kg}$ & Mcal*/kg & BTU/lb & $\mathrm{CO}_{2} /(\mathrm{kg} / \mathrm{kWh})$ & $\mathrm{CO}_{2} / \mathrm{BTU}^{* *}$ \\
\hline Carbon & 32.6 & 7.8 & 14021 & -- & 119 \\
\hline Coal+ & 36 & 8.6 & 15445 & 1.18 & 97 \\
\hline Diesel & 45 & 11 & 19300 & 0.85 & 73 \\
\hline Ethanol & 30 & 7 & 12800 & -- & 66 \\
\hline Gasoline & 47 & 11 & 20400 & 0.83 & 69 \\
\hline Natural gas & 54 & 13 & 23000 & 0.53 & 49 \\
\hline
\end{tabular}

Source: [6, 9]. [M = one million; J=joules; $1 \mathrm{~kg}$-cal=3.96BTU; $1 \mathrm{~g}$-cal=4.19 joules; $1 \mathrm{~kg}=2.205 \mathrm{lb} ; 1$ million joules=0.278 kilowatt-hours, ${ }^{*}$ gram calories;

** grams $\mathrm{CO}_{2} / 1000 \mathrm{BTU}$ or $\left.\mathrm{kg} \mathrm{CO} / \mathrm{MBTU}\right]$.

During the $8^{\text {th }}$ Malaysian Development Plan period (2001-2005), the development of the energy sector was focused on ensuring a secure, reliable and cost-effective supply of energy. Fundamentally, the aim was to minimize the negative impacts of energy production, transportation, conversion, utilization and consumption on the environment. But what would be the appropriate procedure? Connecting to their latest energy policy, this study tried to find out some drawbacks of their policies. Nevertheless, some researchers addressed pollution control industry to reduce pollution emission such as the air pollution control industry should be factored into the environmental analysis that could become a new dimension never being considered. The rationale is that the more the pollution impact, the better the pollution control industry which could trigger a new pipeline of economic growth as such in the long run overall pollution would decrease.

Some researchers also addressed the gray techniques to reduce pollution and environmental cost allocation. In particular, Wu and Chang [4] genetic-algorithm-based (GAbased) grey mathematical programming technique for assessing the impacts of recent pollution charges and water resource fees to a textile-dyeing factory. Their research findings indicate that the grey input-output analysis is an applicable tool to evaluate various environmental cost impacts influential for corporate production planning and management. Another interesting research has done by $\mathrm{Wu}$ and Chang [5] regarding environmental costs and corporate decision-making process. Their research illustrates the miniaturized level framework of green accounting for an individual company and demonstrates how the input-output analysis model can be used to support environmental cost allocation among interacting departments in the participating company. Those kinds of research could be applied in electricity industry.

Principally, Hamid et al. [6] estimated that for electricity generation the change in fuel mix (from fossil fuel to coal) has environmental implication. They estimated the $\mathrm{CO}_{2}, \mathrm{SO}_{2}$ and $\mathrm{NO}_{\mathrm{x}}$ emission from the thermal electricity station and estimated the average efficiency of Malaysian power plants from 2000 to 2020. Similar energy Input- Output (I-O) studies can be found in the studies of Casler, S. and Wilbur, S. [7] and Howdon, D. and Pearson, P. [8] analysis. Particularly, Casler, S. and Wilbur, S. [7] presents the basic theory and assumptions of energy I-O analysis, discusses its role in the area of energy analysis, and considers problems associ- ated with its use. They estimated the direct and indirect, in determining total energy requirements which consider energy inputs from all producing sources (which can be found in our studies, Tables $\mathbf{2 A}$ and $\mathbf{2 B}$ ). Such intensities are useful in determining expected changes in energy demand given changes in the composition of industrial output. On the other hand, Howdon, D. and Pearson, P. [8] show how a number of the complex interrelationships between energy, environment and economic welfare can be investigated with the aid of input-output (I-O) model of the UK. The paper reviews relevant past applications of I-O analysis in the energyenvironment area and describes its operation. It is used to simulate the effects of a variety of policies and possibilities, not only through changes in exogenous variables (final demand and income taxes and transfers) but also through changes in the structural matrices and their coefficients. In each case the full effects, direct, indirect and income induced, can be traced and the changes in comparative static equilibrium values discovered. In this way, policy, issues connected with energy use and environmental impacts, employment and economic welfare have been investigated.

However, for electricity generation the change in fuel mix for the electricity sector has environmental implication in terms of emission trade-offs (Hamid et al. [6]). Among the four fuels, gas and hydro are the most environmentally sound options in terms of air pollution emissions. At the same time, switching to more coal would imply greater particulate emissions and solid-waste generation. Hence, the primary objective of this paper is, therefore, to investigate pollution emission from electric power industries in the Malaysian economy for the year 1991 and 2000. Principally, the fundamental objective is to assess the relative pollution emissions arising from the Fifth Fuel Diversification Strategy (Malaysian current energy policy until 2020) and comments on that fuelmix envisioned policy in the electric power industry for vision 2020. In particular, we would compare the emissions between the 1991 and 2000 fuel-mix, business- as-usual fuel-mix and proposed fuel-mix policy for the year 2020 .

The paper is organized as follows. A review of Malaysian electricity sector is presented in section 2 . In section 3 , we present the underlying model, which is based on inputoutput techniques and it shows how to estimate the pollution emission from fossil fuels. Results and discussions are presented in section 4 . In section 5 a relative pollution emissions scenario is analysed. The discussions and conclusions are given in section 6 and 7 respectively. 


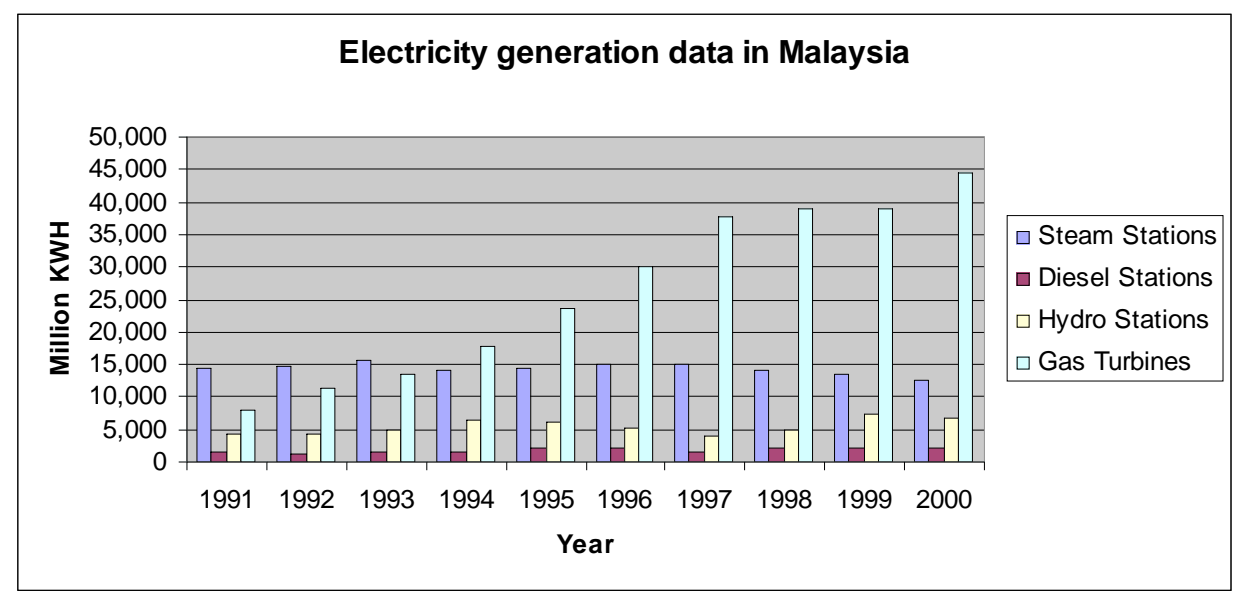

Source: [10].

Fig. (1). Electricity generation data in Malaysia (1991-2000 Million KWh).

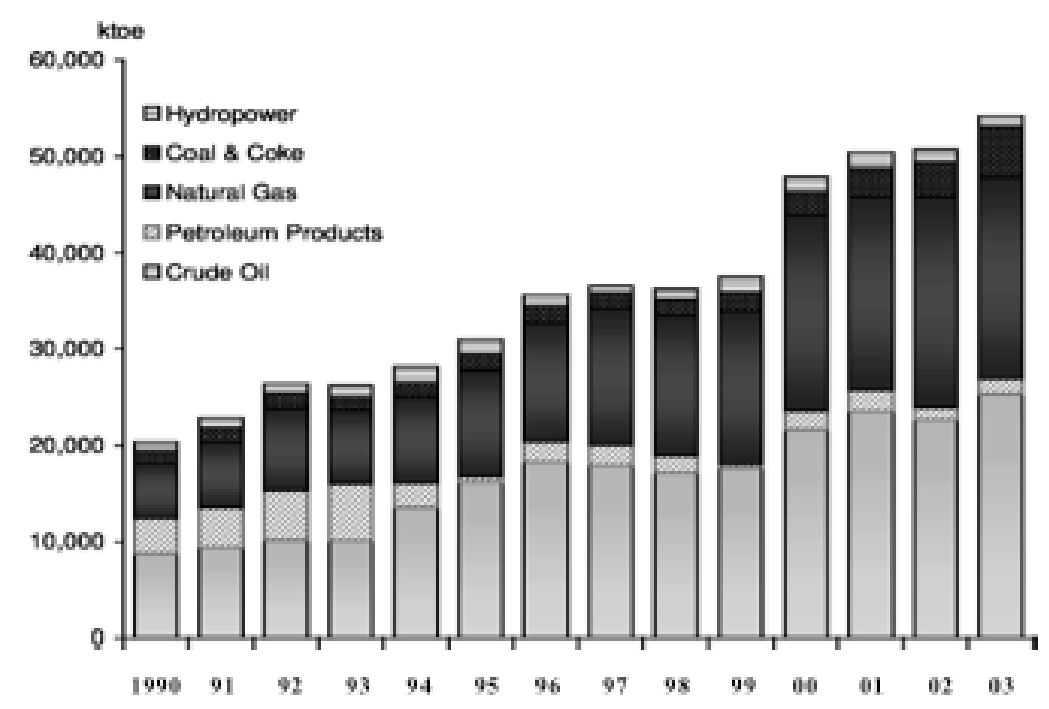

Source: [1].

Fig. (2). Electricity Generation Fuel Mix in Malaysia (1990-2003).

\section{MALAYSIAN ELECTRICITY SECTOR}

The electricity sector of Malaysia is composed of two main sub-sectors namely thermal power plants and hydroelectric plants. Electricity is supplied by the three utility companies, namely Tenaga National Berhad (TNB) in Peninsular Malaysia, Sabah Electricity Supply Berhad (SESB) and Sarawak Electricity Supply Corporation (SESCO). As a newly industrialized country, electricity is an indispensable factor for Malaysia's economic development and the trend in electricity consumption is increasing. The capacity and the electricity generation by different power plants in Malaysia from 1991-2000 is shown in Fig. (1). The electricity generation in Malaysia mostly depends on fossil fuel and coal, and burning these fossil fuel and coal are the prime sources of emission for the environmental impact. Fuel Diversification Strategy in Malaysia was introduced as an extension of the National Energy Policy for sustainable energy use.

The rationale for this policy initiative was to reduce the country's over reliance on oil, particularly in the electricity generation sector. This policy aimed for a supply mix of natural gas, hydropower, oil and coal. Malaysia hopes to gradually change fuel use by the year 2020. In the light of the Government's recent sustainable energy policy to alter the fuel mix for the electricity sector in order to optimize the use of the various fuel sources, the share of natural gas decreased from $74.9 \%$ in 2000 to $65.3 \%$ in 2003. Subsequently, the share of coal in the fuel mix increased from $9.7 \%$ in 2000 to $24.6 \%$ in 2003 whereas the share of fuel oil and diesel oil decreased from $5 \%$ in 2002 to $3.8 \%$ in 2003. The share of hydro power also decreased by $3.8 \%$ in 2003 to $6.3 \%$ compared to $10.4 \%$ in 2000 [1,2].

Fig. (2) illustrates the fuel diversification strategy, where the share of oil and diesel in electricity generation fuel mix decreased while the share of gas and coal increased. The figure also illustrates that electricity consumption and electricity intensity of Malaysia from 1990-2003 increased. Fig. (3) shows the trends in GDP and electricity consumption in Malaysia from 1990-2003. Although the generation and demand of electricity is increasing, the Malaysian utility sector is still less efficient than that of Sweden, Japan, Finland, Canada, Brazil, Italy and Norway [6]. This is due to the fact 


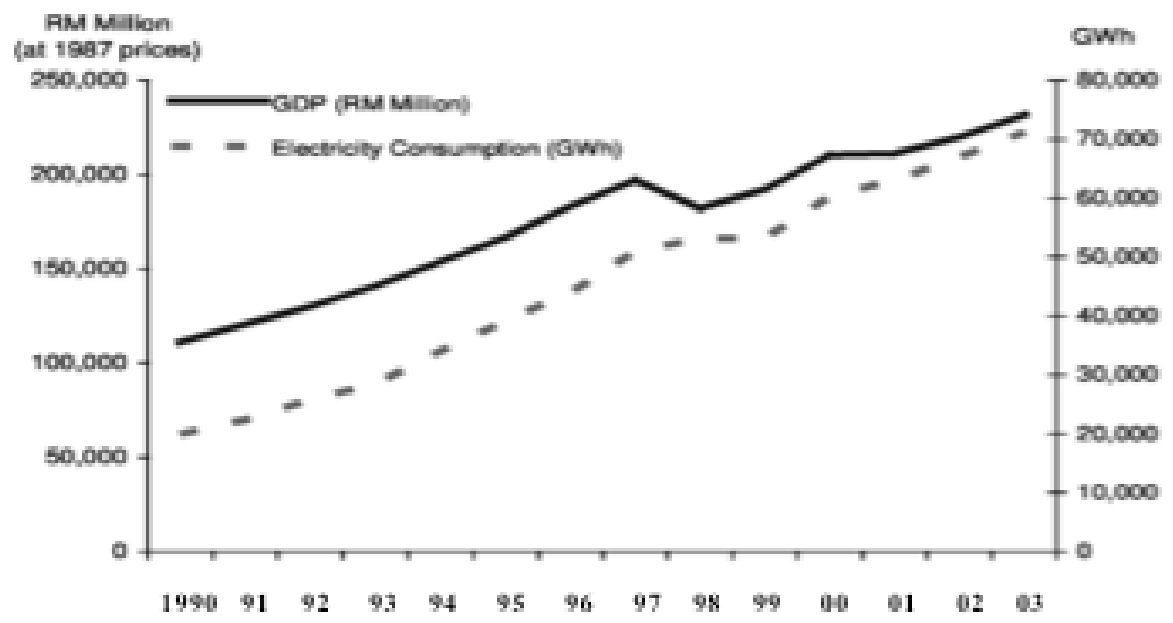

Source: [2].

Fig. (3). Trends in GDP and electricity consumption in Malaysia (1990-2003).

that electricity generation in these countries largely depends on hydroelectricity. The irreversibility losses of their utility sector are relatively small compared to Malaysia where electricity is generated mainly from thermal power plants.

\section{METHODOLOGY}

To achieve the above stated objective, the methodology employed in this paper is based on Leontief's input-output framework [11-13] where the structure of an economy is analyzed in terms of interrelationships between production sectors. In this study the I-O model is used to discuss the core aspects of its extensions considering the environmental and emission issues and to calculate an emission intensity and multiplier matrix to show industrial output as well as energy requirements, followed by level of emission derived from the energy and resources use attributable to given sets of final demand. Generally, the input-output model describes the relationships among economic sectors through the use of a system of linear equations, which represent each sector's identity between the total output produced and the output purchased and consumed by all the other sectors of the system. In other words, everything produced by a sector is purchased and consumed respectively by the other ones as inputs or by the consumer as final demand. In matrix notation this system of linear equations is;

$$
\mathbf{x}=\mathbf{A x}+\mathbf{f}
$$

This equation is the fundamental equation of the open Leontief system, which states that the gross output $(\mathbf{x})$, is the sum of all intermediate demand (Ax) and final demand (f). In that equation, $f$ is final demand vector, $\mathbf{x}$ is a vector of total output with elements $\mathbf{x}_{i}$ where $i(=1, \ldots, \mathrm{n})$ is the number of sectors in the economy. Matrix $\mathbf{A}$ is the direct input requirement matrix with elements indicating the direct input from sector $i$ used by sector $j$ to produce one ringgit's worth of output. The solution of the I-O model can be written as $\mathbf{x}=(\mathbf{I}-\mathbf{A})^{-1} \mathbf{f}$, where $(\mathbf{I}-\mathbf{A})^{-1}$ known as 'Leontief inverse' or technological matrix, $\mathbf{A}$ input coefficients, and $\mathbf{I}$ is a $\mathrm{n} \times \mathbf{n}$ identity matrix (e.g. details analytical forms can be found by Miller and Blair [11], p. 237).

\subsection{The Emission Model}

An environmental extension of the input-output model can be obtained by incorporating a matrix $\boldsymbol{e}$ which includes each sector's direct and indirect resources (i.e. oil and gas) use for one unit of their monetary output [11]. The multiplication of the environmental matrix $\boldsymbol{e}$ and the Leontief inverse $(\mathbf{I}-\mathbf{A})^{-1}$ gives the multiplier matrix $\varepsilon$, which shows the (direct and indirect) resources intensity of each sector:

$$
\varepsilon=\boldsymbol{e}(\mathbf{I}-\mathbf{A})^{-1}
$$

To test how much pollution emission is generated by electricity, there is a need to multiply pollutants emission factor (shown below) with $\varepsilon$, using the guidelines of the 'Intergovernmental Panel on Climate Change' (IPCC). (In the case of crude petroleum (oil), the carbon emission factor equals $0.77 \mathrm{mt}$ of carbon per mtoe of oil, and $99.25 \%$ of the carbon oxidized. The molecular weight of $\mathrm{CO}_{2}$ is 44.01 and that of Carbon $(\mathrm{C})$ is 12.011 thus the molecular weight ratio equals $44.01 / 12.01=3.66 \mathrm{mt}$ of $\mathrm{CO}_{2}$ per $\mathrm{mt}$ of $\mathrm{C}$. Consequently, the combustion of one mtoe of oil results in generation of $0.77 \times 0.9925 \times(44.01 / 12.01)=2.80 \mathrm{mt}$ of $\mathrm{CO}_{2}$ emission. Multiplication of this number by mtoe/(million $\mathrm{RM})$ ratio of oil industry gives $\mathrm{mt}$ of $\mathrm{CO}_{2}$ that is generated by the combustion of one million RM of oil). The conversion factors are estimated as follows:

$$
\begin{gathered}
\left(\begin{array}{l}
\text { Emissions per } \\
\text { mtoe of fuel }
\end{array}\right)=\left(\begin{array}{l}
\text { Fuel's emission } \\
\text { factor }
\end{array}\right) \times \\
\left(\begin{array}{l}
\text { Fraction of } \\
\text { pollution oxidized }
\end{array}\right) \times\left(\begin{array}{l}
\text { Molecular weight } \\
\text { ratio of emission }
\end{array}\right)
\end{gathered}
$$

More concretely, the final step is to calculate how much input of fossil fuels, and coal are required to produce electricity that is required (directly and indirectly) to satisfy final demand $f$ (diagonal). Using input coefficients corresponding fuel oil, and coal sectors of $\mathbf{A}$ and for any exogenously specified final demand of electricity $\hat{\tilde{f}}$, the total emission such as 
Table 2A. Sectoral Energy Intensity and Direct \& Indirect Energy Demand -2000

\begin{tabular}{|c|c|c|c|c|c|c|}
\hline Sector & \multicolumn{2}{|c|}{$\begin{array}{c}\text { Sectoral Energy Intensity } \\
(\boldsymbol{e})\end{array}$} & \multicolumn{2}{c|}{ Sectoral Energy Multipliers $(\varepsilon)$} & \multicolumn{2}{c|}{$\begin{array}{c}\text { Direct \& Indirect Energy for Final Demand } \\
(\text { TOE*/RM) }\end{array}$} \\
\hline & Coal & Oil & Coal & Oil & \multicolumn{2}{c|}{ Coal } \\
\hline Fuel \& other Electricity & 0.1002 & 0.8284 & 0.1039 & 0.8595 & $302,887.59$ & $2,505,600.41$ \\
\hline Hydro Electricity & 0.0000 & 0.0000 & 0.0004 & 0.0034 & 126.69 & $1,076.87$ \\
\hline
\end{tabular}

$*$ TOE $=$ Total Oil Equivalent $(\mathrm{mtoe}=$ toe $/ 1000 \times 1000)$; ${ }^{\text {Direct }} \&$ indirect energy demand $=\boldsymbol{e}(\mathbf{I}-\mathbf{A})^{-1} \mathbf{f}$.

Table 2B. Sectoral Energy Intensity and Direct \& Indirect Energy Demand -1991

\begin{tabular}{|c|c|c|c|c|c|c|}
\hline Sector & \multicolumn{2}{|c|}{ Sectoral Energy Intensity $(\boldsymbol{e})$} & \multicolumn{2}{|c|}{ Sectoral Energy Multipliers $(\boldsymbol{\varepsilon})$} & \multicolumn{2}{c|}{$\begin{array}{c}\text { Direct \& Indirect Energy for Final Demand } \\
(\text { TOE*/RM) }\end{array}$} \\
\hline & Coal & Oil & Coal & Oil & Coal & $1,428,106.19$ \\
\hline $\begin{array}{c}\text { Fuel \& other Elec- } \\
\text { tricity }\end{array}$ & 0.0281 & 1.5715 & 0.2836 & 1.5856 & $255,435.78$ & 108.83 \\
\hline Hydro Electricity & 0.0000 & 0.0000 & 0.0006 & 0.0031 & 608.44 \\
\hline
\end{tabular}

*TOE=Total Oil Equivalent $\left(m\right.$ toe $=$ toe $/ 1000 \times 1000 ;{ }^{a}$ Direct $\&$ indirect energy demand $=\boldsymbol{e}(\mathbf{I}-\mathbf{A})^{-1} \mathbf{f}$.

carbon, sulphur and nitrogen emission $\left(\mathrm{CO}_{2}, \mathrm{SO}_{2}, \mathrm{NO}_{\mathrm{x}}\right.$ respectively) can be written as:

$$
\left[\begin{array}{l}
c^{\prime} \\
s^{\prime} \\
n^{\prime}
\end{array}\right]=\left[\begin{array}{ll}
c_{1} & c_{2} \\
s_{1} & s_{2} \\
n_{1} & n_{2}
\end{array}\right]\left[\begin{array}{l}
\left(a_{1}^{\prime}+b_{1}^{\prime}\right) \\
\left(a_{2}^{\prime}+b_{2}^{\prime}\right)
\end{array}\right] \mathbf{L} \hat{\tilde{f}} \equiv\left[\begin{array}{l}
d^{\prime} \\
f^{\prime} \\
g^{\prime}
\end{array}\right] \mathbf{L} \hat{\tilde{f}}
$$

where, $c^{\prime}, s^{\prime}, n^{\prime}$ express the row vectors of total emissions of $\mathrm{CO}_{2}, \mathrm{SO}_{2}, \mathrm{NO}_{\mathrm{x}}$ at the sectoral level, respectively, and $\mathrm{c}_{1} \ldots . \mathrm{n}_{2}$ are conversion factors and $\mathrm{a}_{1}{ }_{1} \ldots . . \mathrm{b}_{2}{ }_{2}$ are energy intensity $\boldsymbol{e}$ vector as well as $\left(\mathrm{a}^{\prime}{ }_{1}+\mathrm{b}^{\prime}{ }_{1}\right)$ indicates the coefficients of domestically produced fossil oil plus imported oil and $\left(\mathrm{a}_{2}{ }_{2}\right.$ $+b_{2}^{\prime}$ ) indicates the coefficients of domestically produced coal plus imported coal.

\subsection{Data Sources}

The study uses an input-output approach based on the two input-output tables 1991 and 2000 of the Malaysian economy. The $\mathrm{CO}_{2}, \mathrm{SO}_{2}$ and $\mathrm{NO}_{x}$ emissions from fossil fuel combustion are estimated by Inter Governmental Panel on Climate Change (IPCC) 1996 guidelines. The information of energy balance from 1991-2000 of Malaysian economy is taken from Ministry of Energy, Water and Communications, Malaysia and energy statistics and balances of Non-OECD countries (1991-1992) and energy balances of Non-OECD countries (1999-2000) [14,15]. The Input-Output table of 1991 contains 92 sectors and 2000 table contains 94 sectors. For the purpose of empirical studies, this study aggregated both I-O tables $3 \times 3$ sectors in order to achieve the desired results. However, as the I-O tables identify electricity and gas sectors in a single sector Standard Industrial Classifica- tion, disaggregation of the electricity sector from both I-O tables is required to estimate the electricity emission for 1991 and 2000. The electricity sector includes the generation, transmission, distribution and supply activities related to the production and use of electricity.

\section{RESULTS AND DISCUSSION}

\subsection{Energy and Sectoral Energy Intensity}

The input-output model has been used first (e.g. Leontief fundamental equation $\mathbf{x}=(\mathbf{I}-\mathbf{A})^{-1} \mathbf{f}$, and multiplier matrix $\left.\varepsilon=\boldsymbol{e}(\mathbf{I}-\mathbf{A})^{-1}\right)$ to signal out the sectoral energy intensity that uses fossil oil and coal in the electricity sector in the Malaysian economy from 1991 to 2000. Tables 2A and 2B contain the estimated corresponding figures. The sectoral direct (e=energy/industry output or TOE/RM) and indirect energy intensities $\left(\boldsymbol{e}(\mathbf{I}-\mathbf{A})^{-1}\right)$ to the total output and to the final demand, represents thousand tonnes of $\mathrm{CO}_{2}, \mathrm{SO}_{2}$, and $\mathrm{NO}_{\mathrm{x}}$ emitted per thousand RM (ringgit Malaysia) of final demand for each sector (e.g. detailed emission estimation procedures can be found in Abdul Hamid et al. [6]). Concerning sectoral energy intensities (except hydro-electricity), the energy intensity of oil in 1991 is higher compared to 2000 in the fuel and other electricity sector. In contrast, in 2000 coal intensity dominates due to Malaysian Government's recent sustainable energy policy to alter the fuel mix for the electricity sector.

\subsection{The $\mathrm{CO}_{2}, \mathrm{SO}_{2}$, and $\mathrm{NO}_{\mathrm{x}}$ Emission Produced by the Economy}

This section is devoted to quantify the changes in the amount of emissions when there are exogenous and unitary changes in the final demand of activities. Table $\mathbf{3 A}$ shows the percentage change in the technical coefficients from 
Table 3A. Percentage Changes in Technical Coefficient from 1991-2000

\begin{tabular}{|c|c|c|c|}
\hline Sectors & Non-Electricity & Fuel and Other Electricity & Hydro Electricity \\
\hline \hline Non- electricity & -0.1156745 & 0.03640233 & -0.48695201 \\
\hline Fuel and other Electricity & -0.1016468 & 5.31360287 & 2.12493945 \\
\hline Hydro Electricity & -0.1004123 & 5.31360287 & 2.12493945 \\
\hline
\end{tabular}

Table 3B. Percentage Changes in Leontief Inverse from 1991-2000

\begin{tabular}{|c|c|c|c|}
\hline Sectors & Non-Electricity & Fuel and Other Electricity & Hydro Electricity \\
\hline \hline Non- electricity & -4.97208 & 1.501012 & -49.73915 \\
\hline Fuel and other Electricity & -11.86204 & 2.831774 & 108.458652 \\
\hline Hydro Electricity & -11.86204 & 321.171739 & 0.210616 \\
\hline
\end{tabular}

1991-2000. The percentage change in the direct requirements in the fuel and other electricity and hydro electricity segments have very low share i.e. less than $5 \%$. This confirms that the contribution of the utility sectors was almost the same and roughly identical during our empirical period.

Table 3B illustrates the percentage change in the Leontief inverse coefficient between 1991 and 2000. This reveals that in fuel and other electricity and hydro electricity, the share was high in total requirements than direct requirement and in some cases the percentage share was low in total requirement than direct requirement. Likewise, hydro electricity share increased by $108.5 \%$ from the fuel and other electricity sectors. However the share of the fuel and other electricity was almost the same as fuel and other electricity at $2.83 \%$. The interpretation is that the total requirements from the fuel and other electricity segment to satisfy one unit of final demand for hydro electricity has increased $(108.5 \%)$ than direct requirements and the total requirements from hydro electricity segment to satisfy one unit of final demand for fuel and other electricity has increased $(321.17 \%)$ than direct requirements.

Although the share changes of coefficients from 19912000 are almost same, the total emission in all respects $\left(\mathrm{CO}_{2}\right.$, $\mathrm{SO}_{2}$, and $\mathrm{NO}_{\mathrm{x}}$ ) was higher in 2000 than 1991, due to higher final demand of electricity in 2000. The figures of Tables $\mathbf{4 A}$ and $4 \mathrm{~B}$ illustrate sectoral $\mathrm{CO}_{2}, \mathrm{SO}_{2}$ and $\mathrm{NO}_{\mathrm{x}}$ emission for the year 2000 and 1991. (All emission and emission factors are estimated by the authors according to "Revised 1996 IPCC Guidelines for national Greenhouse Gas Inventories, IPCC/OECD/IEA Inventory Programme, Paris [16]).

For example, $\mathrm{CO}_{2}$ emission was $5.35 \mathrm{mt}(\mathrm{mt}=$ million ton), $7.58 \mathrm{mt}$ in 1991 and $38.17 \mathrm{mt}, 27.91 \mathrm{mt}$ in 2000 from coal and oil respectively ${ }^{4}$. The $\mathrm{SO}_{2}$ emission was $15.95 \mathrm{tt}$ (kilo ton), 80.79 tt in 1991 and 83.99 tt, 501.83 tt in 2000

\footnotetext{
${ }^{4}$ The IEA [15] also estimated $\mathrm{CO}_{2}$ emission for Malaysia from energy related utilization for the year 2000. According to their estimation the $\mathrm{CO}_{2}$ emission was 118 million ton, of which almost $60 \%$ (67 million ton) from fossil fuel and coal energy utilization. Our estimation for the year 2000 also showing $(38.17 \mathrm{mt}$ from coal $+27.91 \mathrm{mt}$ from fossil oil $=66.08$ million ton) close figures to the IEA [15] statistics.
}

and NOx emission $156.99 \mathrm{tt}, 8.84 \mathrm{tt}$ in 1991 and $466.35 \mathrm{tt}$ $13.86 \mathrm{tt}$ in 2000 from coal and oil respectively. However in the sectoral case in 1991 the $\mathrm{CO}_{2}$ emission from oil $(7.5 \mathrm{mt})$ was higher than coal $(5.3 \mathrm{mt})$ and in the case of NOx, coal emission $(156.99 \mathrm{tt})$ was higher than oil emission $(8.84 \mathrm{tt})$. On the other hand, in terms of $\mathrm{CO}_{2}$ emission, coal emission (38.17 $\mathrm{mt})$ was much higher than oil emission $(27.91 \mathrm{mt})$. This is due to Malaysian Government's energy policy to alter the fuel mix for the electricity generation. As indicated by the result, based on current technology and current final demand, the proposed fuel mix would result in higher pollutants generation in 2000 from more coal energy use.

\section{SCENARIO ANALYSIS AND COMMENTS}

\subsection{Changes in Level of Final Energy Demand}

The scenario analysis, based on macro forecasted growth rate formula and $\mathrm{I}-\mathrm{O}$ model is presented in section 3 (Using final demand growth rate given in the development plans, we forecasted final demand, $\mathrm{Y}_{\mathrm{t}}$ from 2000 to 2020 holding 2000 base year as follows: $Y_{t}=Y_{2000}\left(1+r_{Y}\right)^{t}$ where, $t=$ $1,2,3,4,5 \ldots \ldots \ldots . .20$, and ${ }^{\mathrm{r}} \mathrm{Y}$ is the annual final demand growth rate. The same formula we used to estimate energy demand for the year 2020, $\left(\mathrm{Y}_{\mathrm{e}}=\mathrm{Y}_{2000}\left(1+\mathrm{r}_{\mathrm{e}}\right)^{\mathrm{t}}\right.$ where, $\mathrm{t}=$ $1,2,3,4,5 \ldots \ldots \ldots . .20)$, in that case $\mathrm{Y}_{\mathrm{e}}$ indicates energy demand from 2000 to 2020 holding 2000 as base year and ${ }_{\mathrm{e}}^{\mathrm{r}}$ used as annual energy growth rate. The scenario analysis focuses on energy demand (i.e. using forecasting projection) adopting Fifth Fuel Diversification strategy until 2020 and pollution emission for the year 2020 (Malaysian development target) based on information given in the $8^{\text {th }}$ and $9^{\text {th }}$ Malaysia Plan.

\subsection{The $\mathrm{CO}_{2}, \mathrm{SO}_{2}$ and $\mathrm{NO}_{x}$ Emission Scenario for 2020}

Based on 1991 and 2000 pollution intensity with 2020 final demand, the scenario results indicate that the $\mathrm{CO}_{2}$ emission would be $298.34 \mathrm{mt}$ and $330.53 \mathrm{mt}$, the $\mathrm{SO}_{2}$ emission would be $3.16 \mathrm{mt}$ and $3.54 \mathrm{mt}$ and the $\mathrm{NO}_{\mathrm{x}}$ emission would be $2.44 \mathrm{mt}$ and $2.62 \mathrm{mt}$ respectively. In contrast, based on current technology and 2020 final demand, the proposed fuel mix would result in higher pollutants generation in 2020 which are evident in Table 5. In this scenario the new fuel 
Table 4A. Total $\mathrm{CO}_{2}, \mathrm{SO}_{2}$, and NOx Emission in Malaysian Economy in 2000

\begin{tabular}{|c|c|c|c|c|c|c|}
\hline Sector & Coal & Oil & Coal & Oil & Coal & Oil \\
\hline $\begin{array}{l}\text { Fuel and other Electric- } \\
\text { ity }\end{array}$ & $38,174.52$ & $27,914.23$ & 83.99 & 501.83 & 466.35 & 13.86 \\
\hline
\end{tabular}

Table 4B. Total $\mathrm{CO}_{2}, \mathrm{SO}_{2}$, and NOx Emission in Malaysian Economy in 1991

\begin{tabular}{|c|c|c|c|c|c|c|}
\hline \multirow[t]{2}{*}{ Sector } & \multicolumn{2}{|c|}{ Emission / ' 000 Tonnes $\mathrm{CO}_{2}$} & \multicolumn{2}{|c|}{ Emission / ' 000 Tonnes $\mathrm{SO}_{2}$} & \multicolumn{2}{|c|}{ Emission / ' 000 Tonnes NOx } \\
\hline & Coal & Oil & Coal & Oil & Coal & Oil \\
\hline Fuel and other Electricity & $5,352.84$ & $7,589.56$ & 15.95 & 80.79 & 156.99 & 8.84 \\
\hline Hydro Electricity & 2.28 & 3.23 & 0.01 & 0.03 & 0.07 & 0.004 \\
\hline
\end{tabular}

Table 5. Total Environmental Impacts of Electricity Generation for the Year 2020 Based on 1991and 2000 Pollution Intensity, Present Fuel Mix, Business as Usual and Proposed Fuel Mix in Malaysia

\begin{tabular}{|c|c|c|c|c|c|}
\hline $\begin{array}{c}\text { Pollution } \\
\text { Emissions }\end{array}$ & $\begin{array}{c}\mathbf{1 9 9 1} \text { Pollution Inten- } \\
\text { sity (kt) }\end{array}$ & $\begin{array}{c}\mathbf{2 0 0 0} \text { Pollution Inten- } \\
\text { sity (kt) }\end{array}$ & Present Fuel Mix (kt) & $\begin{array}{c}\text { Business as Usual Fuel } \\
\text { Mix (kt) }\end{array}$ & Proposed Fuel Mix (kt) \\
\hline \hline $\mathrm{CO}_{2}$ & 298,339 & 330,529 & 350,559 & 398,139 & 800,519 \\
\hline $\mathrm{SO}_{2}$ & 3,159 & 3,544 & 3,840 & 3,589 & 3,840 \\
\hline $\mathrm{NO}_{x}$ & 2,445 & 2,616 & 2,316 & 2,985 & 18,316 \\
\hline
\end{tabular}

mix would result in $800.52 \mathrm{mt}$ of $\mathrm{CO}_{2}, 3.84 \mathrm{mt}$ of $\mathrm{SO}_{2}$ and $18.32 \mathrm{mt}$ of $\mathrm{NO}_{\mathrm{x}}$ in the year 2020 . Where as, based on present fuel mix and 2020 final demand our results find very similar emission like 'business-as-usual' fuel mix results and the (scenario) analysis indicates less emission compared to the proposed fifth fuel mix strategy, resulting in merely $350.56 \mathrm{mt}$ of $\mathrm{CO}_{2}, 3.84 \mathrm{mt}$ of $\mathrm{SO}_{2}$ and $2.98 \mathrm{mt}$ of $\mathrm{NO}_{\mathrm{x}}$ for the year 2020.

Simply comparing the results of the various fuels-mixes (i.e.1991 and 2000 pollution intensity, present fuel mix, business as usual and proposed fuel mix) indicate interesting outlines for the Malaysian 'Fifth Fuel Diversification Strategy'. Regarding the $\mathrm{CO}_{2}$ emissions, the pollution emissions would be quite high compared to any other policy such as 1991 and 2000 pollution intensity or present fuel mix and business fuel mix strategy. Similarly concerning $\mathrm{NO}_{\mathrm{x}}$ emissions, the pollution emissions for the proposed fuel mix would generate more that 7 times higher than any other fuel mix strategy which would be highly concerning sector for 2020 energy policy. Generation of $\mathrm{SO}_{2}$ would also increased; however, only here in tiny quantity. Simply put, while the Fuel Diversification Strategy place Malaysia in a position that is less dependent on oil, the reduction is compensated by higher generation by coal fuel and hydroelectricity. As such, our findings indicate over all pollution would be increased.

\section{DISCUSSION FOR POLICY OPTIONS}

As a direct consequence of Fuel Diversification strategy, the contribution of oil to the energy mix has dropped drastically from a high $90 \%$ dependence in 1980 to less than $10 \%$ in 2003 as shown [6]. Issues related to the environmental impact were not a big concern at the time when gains from fuel diversification strategy were introduced and the disastrous changes (impact) associated with coal energy did not include the impact on the environment.

Although coal is projected to play a far more important role in the energy mix (according to Fifth Fuel Diversification strategy), nevertheless, its utilization faces several major challenges as we observed from Table 5. Thus, the environmental problems associated with coal must be closely studied to find new ways to overcome these problems. Technological advances (i.e. energy efficiency in the thermal power plants) must be achieved in the near future to reduce the carbon, sulfur and nitrogen oxides emissions (A. Hamid et al. [6]). To achieve environmental sustainability with the proposed fuel mix, greater emphasis must be given in improving 
the conversion efficiency of energy and clean coal technology. Clean-coal technology, which includes electrostatic precipitators and flue gas desulfurization technology for air pollutants emission control, must be utilized in the new coalfired power plants to ensure that environmental standards are met.

A. Hamid et al. [6] estimated that in Malaysia annual average efficiency in the coal electricity has been moderately increasing from 1995 to 2000 at a rate of about $1.6 \%$ per annum. If this rate of increase persists through 2020, the conversion efficiency would be approximately less than $48 \%$. While this figure is still very low in terms of international standard (70-80\%), it will however, lessen the amount of emission that would have been generated had there been no efficiency gain. With the right efficient technology, the process of coal extraction, movement and more efficient combustion system is a must to help to reduce the environmental concerns associated with the use of coal for producing electricity.

\section{CONCLUSION}

This paper empirically explores the system-wide economic impact of electricity generation and scenario analysis that separately identifies impact on the environment of coal, fuel and hydro generating electricity technologies. This paper also evaluates of $\mathrm{CO}_{2}, \mathrm{SO}_{2}$ and $\mathrm{NO}_{\mathrm{x}}$ emissions for the year 1991 and 2000 based on business as usual techniques and projection of $\mathrm{CO}_{2}, \mathrm{SO}_{2}$ and $\mathrm{NO}_{\mathrm{x}}$ emissions based on business as usual and fuel mix strategy as specified in the Fifth Fuel Diversification Strategy incorporated in the Malaysian Energy Policy. All things remaining the same, our results show that the proposed fuel mix would result in significantly higher $\mathrm{CO}_{2}(800.52 \mathrm{mt}), \mathrm{SO}_{2}(3.84 \mathrm{mt})$ and $\mathrm{NO}_{\mathrm{x}}$ (18.32 mt) emissions in the year 2020. Even though the Fuel Diversification Strategy could provide the needed security and cost effectiveness in future energy supply, nonetheless it appears to have failed to achieve the environmental objective of the Malaysian National Energy Policy that aim to minimize the negative impacts of energy production, transportation, conversion, utilization and consumption on the environment.

From the preceding analysis, it is possible to conclude that the option available for reducing Malaysian emission is to switch from thermal (fossil fuel based) power generated electricity sectors to renewable energy generated electricity sector (i.e. hydro power, solar, biomass etc.) and the high efficiency gains from conventional thermal power plants. The time has come for rethinking about the environmental concern in every step of economic development regarding the emission impacts on the economy. Projections for Malaysian electricity-energy generation for the year 2020 made by this study are analytically important for rethinking of energy-mixed policy and renewable energy for the $10^{\text {th }}$ Malaysian Development Plan (2011-2015) with environmental care and social responsibility in mind.

\section{REFERENCES}

[1] PTM. National Energy Balance of Malaysia; Ministry of Energy, Communications and Multimedia: Malaysia, 2003.

[2] PTM. National Energy Balance of Malaysia; Ministry of Energy, Communications and Multimedia: Malaysia, 2002.

[3] EPU. Ninth Malaysia Plan 2006-2010; Economic Planning Unit: Malaysia, 2006.

[4] Wu, C. C.; Chang, N. B. Grey input-output analysis and its application for environmental cost allocation. Eur. J. Oper. Res., 2003 145, 175-201.

[5] Wu, C.C.; Chang, N.B. Evaluation of environmentally benign production program in the textile dying industry (I): an inputoutput analysis. Civil Eng. Environ. Syst., 2007, 24, 275-298.

[6] Jaafar, A. H.; Al-Amin, A. Q.; Siwar, C. Environmental impact of alternative fuel mix in electricity generation in Malaysia. Renewable Energy, 2008, 33, 2229-2235.

[7] Casler, S.; Wilbur, S. Energy input-output analysis: a simple guide. Resour. Energy, 1984, 6 (2), 187-201.

[8] Hawdon, D.; Pearson, P. Input-output simulations of energy, environment, economy interactions in the UK. Energy Econ., 1995, 17, 73-86.

[9] David, R. Lide. CRC Handbook of Chemistry and Physics. $89^{\text {th }}$ ed.; National Institute of Standards and Technology, CRC press: USA, 2008.

[10] DOS. Malaysia Economic Statistics - Time Series; Department of Statistics: Malaysia, 2003.

[11] Miller, R. E.; Blair, P. D. Input-Output Analysis: Foundations and Extensions; Englewood Cliffs, NJ, Prentice Hall: USA, 1985.

[12] Proops, J. P.; Philip, W. Gay; Stefan, S.; Thomas, S. The lifetime pollution implications of various electricity generations: An inputoutput approach. Energy Policy, 1996, 24, 229-237.

[13] Dietzenbacher, E.; Kakali, M. An Empirical Examination of the Pollution Haven Hypothesis for India: Towards a Green Leontief Paradox? Presented in Input-Output and General Equilibrium: Data, Modeling and Policy Analysis; Brussels: Belgium, 2004, pp. $3-8$.

[14] IEA. Energy statistics and balances of non OECD countries; OECD Publication, 1992.

[15] IEA. Energy statistics and balances of non OECD countries, OECD Publication, 2000.

[16] IPCC. Revised 1996 IPCC Guidelines for National Greenhouse Gas Inventories; IPCC/OECD/IEA Inventory Programme: Paris, 1996.

(C) Al-Amin et al.; Licensee Bentham Open.

This is an open access article licensed under the terms of the Creative Commons Attribution Non-Commercial License (http://creativecommons.org/licenses/by-nc/3.0/) which permits unrestricted, non-commercial use, distribution and reproduction in any medium, provided the work is properly cited. 